\title{
Overcoming employer perceptions of online accounting education with knowledge
}

\author{
Rhonda Richards, Ph.D., C.P.A., C.M.A. \\ Robert Stevens, Ph.D. \\ Lawrence Silver, M.A., M.B.A., D.B.A. \\ Stephanie Metts, M.B.A., C.P.A. \\ Southeastern Oklahoma State University
}

\begin{abstract}
Accounting education is moving toward an online learning environment. While many universities teach in the face-to-face environment, or at least offer that option, there arealso many universities offering online accounting education. Attitudes and intentions of potential employers of accounting students need to be understood by academics as well as by university students.

Accreditation and training can play a key role in effective online accounting education. The purpose of this study was to identify and examine factors that have a significant impact on employer perceptions of online accounting education. A survey was developed from literature review and interviews and then distributed to CPAs in Oklahoma. The research question asked if an accounting degree from an online university would affect the decision to hire an applicant. Of the 220 CPAs surveyed, $41.6 \%$ agreed that it would impact their decisions to hire. The only demographic that significantly impacted this decision was age. The other demographics surveyed: level of education, gender, employment position, and industry did not have a significant impact. The top three concerns identified were the integrity of online courses, opportunities for live interaction, and the design of effective courses. Course design, such as that implemented with Quality Matters, addresses two of the top three concerns. Knowledge of effective online course pedagogy, both by academics and students, and then conveyed to potential employers is necessary to help overcome the concerns for online accounting education.
\end{abstract}

Keywords: Online Education, Accounting, Employer Concerns, Quality Matters

\section{Introduction}

1 ccounting education is changing due to new technology and the popularity and availability of online learning. With the growing availability of technologies, levels of technological understanding and a faster-paced world, online learning is more available now than ever before. And with that availability comes the opportunity for students to choose online learning and attain an education completely online. The advantages of online learning are availability, flexibility, and opportunities for individuals who have other obligations that may prevent them from attending a university fulltime in a face-to-face environment. Along with the changes in education, accreditation standards have adapted to govern the assessment of learning for online courses. Independent organizations, such as Quality 
Matters, specialize in quality online learning initiatives, standards, and training. Educators are learning and adapting to this change, and utilizing standards established through research to attain effective teaching both in the classroom, online and through hybrid classes.

This research will look at the attitudes and intentions of employers in the accounting profession in relation to online learning. Accounting education is unique in that many who attain an accounting degree also attain certification through a national exam. Also, in many states, the certification exam requires more college credit hours than a bachelor's degree. With these additional requirements, the online accounting degree is enhanced with national standards applicable to both traditional and online learning. However, potential employers of accountants may have differing opinions regarding online accounting education despite the leveling that the standardized exam and requirements beyond a traditional bachelor's degree may provide.

\section{Literature Review}

The issue of online learning at the collegiate level is somewhat controversial as a number of academics and practitioners worry that the qualities necessary for success in the workplace are lost in an online environment (Friedman, 2016; Seibold, 2007). A set of key issues need to be addressed by universities delivering online education and understood by potential employers of online students. These include the design of effective courses, assessment issues, training instructors in online pedagogy, and resources for instructors and students (Salimi, 2007). To accomplish this, accounting educators need to focus on accreditation requirements and effective online pedagogy. At the same time, educators need to communicate to potential employers the rigor of online learning and that it is not just an easier way to get a degree.

Employers of accountants concerned with the quality of an online accounting degree can rely on the Certified Professional Accountant (CPA) exam to expose any program of insufficient quality. That is, a student who passes the CPA exam demonstrates an acceptable level of knowledge regardless of the knowledge delivery system.

Currently, every jurisdiction in the United States, except for the U.S. Virgin Islands, requires at least 150 hours of education in order to obtain the CPA license. The education requirement includes recommendations for accounting, communication, and analytical skills (150-Hour Requirement, 2018). While the American Institute of CPAs (AICPA) recommends the additional hours needed beyond an undergraduate degree be obtained in a graduate program, the delivery method is not specified. At the graduate level, the AICPA suggests students take courses to enhance skills in communication, presentation, interpersonal relationships, and integration of technical skills. All these skills are obtainable from online graduate programs with adequate technology and instructors trained in online pedagogy.

The National Association of State Boards of Accountancy (NASBA) stated in its State Board Report (2016) that pass rates for the CPA exam increased when schools 1 ) invested in students and programs, and 2) achieved the Association to Advance Collegiate Schools of Business (AACSB) accreditation. According to the State Board Report (2016), AACSB accreditation contributed to improved pass rates because accredited institutions increased accounting faculty, reduced concentrations, added entry exams, and graduate exit tests.

The pass rate difference, if any, between traditional and online students is beyond the scope of this paper. However, it should be noted that while AACSB accreditation requires business schools to continuously improve the quality of the coursework, instructors, and university, there is no requirement for face-toface learning and many business schools with the AACSB accreditation offer hybrid and online programs 
(Best Business Schools, 2017).

Bunker and Harris (2014) compared the CPA pass rates of students from predominantly online accounting programs and those from traditional programs. Students from the online programs significantly underperformed on the CPA exam compared to face-to-face students. The study included both AACSB accredited and non-AACSB accredited schools. The study did not compare online and traditional pass rates for schools with AACSB accreditation. Given the impact of AACSB accreditation on CPA exam pass rates, the study fails to consider an important variable. Thus, employers who look at this research may underestimate the effect of AACSB accreditation, regardless of delivery system.

Another study, conducted in cooperation with the Big 4 accounting firms, looked at the difference in hiring accounting graduates from not-for-profit and for-profit schools (Lindquist, 2012). Big 4 accounting firm managers and partners reported they had not hired any accounting graduates from a for-profit institution. Lindquist (2012) also looked at CPA exam pass rates for the two types of schools. The results indicated that firms hired mostly from AACSB schools because the pass rate was higher, and because of the quality of faculty and curriculum design. No distinction was made between AACSB schools with online vs. traditional delivery methods.

Quality Matters (QM), a self-supporting national organization that offers faculty training and certification programs, is based on research aimed at improving online education. Bento and White (2010) looked at an online graduate accounting course to see if it met the standards established by QM. They found that when a course did meet QM standards, student evaluations and GPAs both increased.

Scofield and Walsh (2009) asked students who completed an online accounting course what they would recommend to students considering an online course. The authors identified two areas of advice: "Input" themes and "action to take" themes. Input themes were characterized by such advice as time management, organizational skills, and not falling behind in coursework.

Action to take themes included listening to audio lectures, practicing problems, and overall sudyhabits. Of the themes mentioned to be successful in an online course, time management was the most frequently mentioned. There was no indication that students felt taking an online course put them at any disadvantage.

Seibold (2007) studied employers' perceptions of online education in general. Participants reported they did not think online coursework was the equivalent of traditional face-to-face coursework. Employer concerns included a perceived lack of interactivity and community among the students, which lead to a lack of teaming and networking. At the same time, employers noted that online learning likely enhanced self-motivation and technology skills. For these reasons, the participants suggested that hybrid learning environments might be ideal. The study addressed the change in employer perceptions from four years prior to the study to five years into the future.

Research conducted by Grossman and Johnson (2015) surveyed employer perceptions of online accounting degrees for CPAs, but the study was limited to the state of Kentucky. The study focused on several specifics: educational environment, institutional reputation, employer type, and the coursework mix for both undergraduate and graduate students. Interestingly, their research found that the willingness to hire was not affected by the reputation of the university. Further, the Big 4 accounting firms were as willing to hire online accounting graduates as most other smaller firms. There was a caveat to the online graduate, however. Employers wanted their students who had graduate work to have obtained one of their degrees in a traditional format. They were indifferent if it was the graduate or undergraduate degree.

RICHARDS, STEVENS, SILVER \& METTS / DOI: 10.5929/2019.1.14.5 
Burke and Slavin (2000) reported that, in spite of what some may think, accounting education is moving to a distance learning format. This is true for providing accounting knowledge to non-accounting graduates and for continuing education for current employees. The authors presented examples of large accounting firms using technology to incorporate learning in their organizations. The advantages were real-time interaction, cost savings, and the ability to learn without having to go offsite. Reliable technology, high-quality programs, and trained presenters also help firms address the shortage of accountants.

Accountants who hold a certification are required to earn Continuing Professional Education credits (CPEs) throughout their careers. Many CPEs are offered online. In fact, the larger accounting firms provide CPES for their staff in online formats through learning management systems and use quality standards similar to QM (Burke and Slavin, 2000). Many other businesses are employing online learning for training as well (Adler, 2001; Burke and Slavin, 2000). The ultimate approval of the format for CPEs rests at the state level. However, the NASBA already approves of, and sponsors, online CPE courses.

Thus, for CPAs, there has been a significant change to CPEs as they have moved to online formats. These changes will likely increase the acceptance of online learning. Many State Boards of Accounting accept online accounting courses in meeting the course requirements to sit for the CPA exam. The subject of this study, Oklahoma, accepts online accounting courses while Texas requires 30 hours of upper-level accounting to sit for the CPA exam and 15 of those hours are required to be in a face-to-face format (thiswaytocpa.org, 2017). Candidates are advised by the AICPA to contact the state board in their state of residence to determine the requirements to sit for certification exams.

NASBA approves CPE credits offered online by CPAacademy.org, which was founded in 2012. Scott Zarret, President of CPAacademy.org, recently conducted a presentation on the future of online CPEs and the impact technology is having on the accounting profession. Based on information from Ohio State University and KMPG News, CPEs in the future will not only be online but also will be available from such venues as Massive Open Online Courses or MOOCs (Zarret, 2016). These changes in accounting education at the firm level will aid employers in understanding the quality of an online undergraduate degree in accounting.

Educators and students need to understand the attitudes of potential employers so that they may design and explain online accounting education. Using the tolls of accreditation, assessment, and national standards, educators can communicate with potential employers to help them understand the impact online learning has on accounting education. In order to work with the workforce on the ways education is adapting to the needs of society, online accounting educators first need to understand current perceptions.

\section{Research Design and Methodology}

The purpose of this study was to identify and examine factors that have a significant effect on employer perceptions of online accounting education and to test the significance between these factors. To understand this, we developed a survey-based research design to answer our research questions. The following sections present the research design and the method used for data collection, as well as the validity tests used to measure the outcomes.

\section{Research Design and Data Collection}

A series of interviews with corporate managers, human resource managers, bank managers, CPAs, and CPA firm partners enabled the refinement and better understanding of the survey questions from the

RICHARDS, STEVENS, SILVER \& METTS / DOI: 10.5929/2019.1.14.5 
literature review. In addition, the interviews provided meaningful information related to the research topic which was addressed in the development of the survey instrument. After the interviews were completed, a survey was developed to address the issues identified in the interviews, as well as what we found in the literature review.

The research design was an online, self-administered questionnaire distributed to 7,992 active CPAs in the state of Oklahoma. In total, 222 responses were collected and analyzed. The survey defined online, face-to-face and hybrid learning and then asked a series of questions related to hiring accountants and hiring CPAs. The survey also asked questions to gather information related to the knowledge of accreditation, transcripts, and online learning. QM was also defined before questions addressed the importance of utilizing this method in the development of online courses. Many questions were based on a 7-point Likert scale, but some were fill in the blank and ranking of criteria. The survey was delivered via Survey Monkey with an introductory email from professors in the school of business.

The questionnaire included questions about hiring factors such as frequency, method, important factors, and characteristics. Then, we asked about the importance of the educational background of students such as institution, accreditation, and method of learning. Finally, participants were asked to identify demographics such as age, education, licensure, gender, employment position, and industry. We were most interested in understanding the impact of demographics of age, education, gender, employment position, and industry. We also asked participants to rank their concerns with online courses. The list of concerns that was given for ranking was gathered from the literature review from past studies on online educational concerns.

\section{Construct Validity and Data Analysis}

Table 1

Overall Results

\begin{tabular}{|l|c|c|c|c|c|c|}
\hline \multicolumn{1}{|c|}{ Statement } & $\begin{array}{c}\mathbf{1} \\
\text { Strongly } \\
\text { Disagree }\end{array}$ & $\begin{array}{c}\mathbf{2} \\
\text { Disagree }\end{array}$ & $\begin{array}{c}\mathbf{3} \\
\text { Neutral }\end{array}$ & $\begin{array}{c}\mathbf{4} \\
\text { Agree }\end{array}$ & $\begin{array}{c}\mathbf{5} \\
\text { Strongly } \\
\text { Agree }\end{array}$ & $\begin{array}{c}\text { \# of } \\
\text { Responses }\end{array}$ \\
\hline $\begin{array}{l}\text { An accounting } \\
\text { degree from an } \\
\text { online university } \\
\text { would affect } \text { my } \\
\text { decision to hire } \\
\text { an applicant. }\end{array}$ & 4 & 22 & 54 & $\mathbf{9 1}$ & 47 & \\
\hline
\end{tabular}

In reviewing the results by age regarding the attitudes toward an applicant having an online accounting degree, the Chi-Square test revealed significance at 0.047 (see Table 2).

Table 2

Results by Respondent's Age

\begin{tabular}{|l|c|c|c|c|c|}
\hline & $\mathbf{2 6 - 3 5}$ & $\mathbf{3 6 - 4 5}$ & $\mathbf{4 6 - 5 5}$ & $\mathbf{> 5 5}$ & \# of Responses \\
\hline Strongly Disagree & 0 & 2 & 1 & 1 & 4 \\
\hline Disagree & 1 & 8 & 3 & 10 & 22 \\
\hline Neutral & 4 & 8 & 13 & 29 & 54 \\
\hline Agree & 13 & 16 & 30 & 32 & 91 \\
\hline Strongly Agree & 1 & 5 & 16 & 22 & 44 \\
\hline
\end{tabular}


In reviewing the results by the respondent's level of education, the Chi-Square test revealed no significance at 0.426 (see Table 3).

Table 3

Results by Respondent's Level of Education

\begin{tabular}{|l|c|c|c|c|}
\hline & Doctorate & Masters & Bachelors & $\begin{array}{c}\text { \# of } \\
\text { Responses }\end{array}$ \\
\hline Strongly Disagree & 0 & 3 & 1 & 4 \\
\hline Disagree & 1 & 7 & 14 & 22 \\
\hline Neutral & 1 & 19 & 34 & 54 \\
\hline Agree & 1 & 44 & 46 & 91 \\
\hline Strongly Agree & 3 & 16 & 27 & 46 \\
\hline
\end{tabular}

In reviewing the results by the respondent's gender, the Chi-Square test revealed no significance at 0.301 (see Table 4).

Table 4

Results by Respondent's Gender

\begin{tabular}{|l|c|c|c|}
\hline & Male & Female & $\begin{array}{c}\text { \# of } \\
\text { Responses }\end{array}$ \\
\hline Strongly Disagree & 2 & 2 & 4 \\
\hline Disagree & 13 & 4 & 17 \\
\hline Neutral & 30 & 13 & 43 \\
\hline Agree & 42 & 28 & 70 \\
\hline Strongly Agree & 20 & 19 & 39 \\
\hline
\end{tabular}

In reviewing the results by the respondent's employment position, the Chi-Square test revealed no significance at 0.978 (see Table 5).

Table 5

Results by Respondent's Employment Position

\begin{tabular}{|l|c|c|c|c|c|c|}
\hline & Staff & Management & $\begin{array}{c}\text { Human } \\
\text { Resources }\end{array}$ & Owner & Other & $\begin{array}{c}\text { \# of } \\
\text { Responses }\end{array}$ \\
\hline Strongly Disagree & 1 & 2 & 0 & 1 & 0 & 4 \\
\hline Disagree & 2 & 10 & 0 & 9 & 0 & 21 \\
\hline Neutral & 3 & 24 & 1 & 23 & 3 & 54 \\
\hline Agree & 6 & 47 & 2 & 28 & 5 & 88 \\
\hline Strongly Agree & 2 & 23 & 0 & 15 & 2 & 42 \\
\hline
\end{tabular}

In reviewing the results by the respondent's industry, the Chi-Square test revealed no significance at 0.068 (see Table 6). 
Table 6

Results by Respondent's Industry

\begin{tabular}{|l|c|c|c|c|c|c|}
\hline & $\begin{array}{c}\text { Public } \\
\text { Accounting }\end{array}$ & Service & Merchandising & Manufacturing & Other & \# of Responses \\
\hline Strongly Disagree & 0 & 2 & 0 & 0 & 0 & 2 \\
\hline Disagree & 12 & 1 & 0 & 2 & 4 & 19 \\
\hline Neutral & 28 & 4 & 1 & 0 & 16 & 49 \\
\hline Agree & 36 & 17 & 2 & 7 & 23 & 85 \\
\hline Strongly Agree & 18 & 6 & 0 & 1 & 19 & 44 \\
\hline
\end{tabular}

The respondents were asked to rank their concerns with the online courses. The results are reported in Table 7.

Table 7

Respondent's Concerns with Online Courses

\begin{tabular}{|l|c|}
\hline \multicolumn{1}{|c|}{ Concern } & Percentage \\
\hline Integrity of online courses & $68.2 \%$ \\
\hline Opportunities for live interaction & $58.7 \%$ \\
\hline Design of effective courses & $45.7 \%$ \\
\hline Career preparation & $42.6 \%$ \\
\hline Accreditation & $41.7 \%$ \\
\hline Learning value of distance education & $39.0 \%$ \\
\hline Assessment issues & $34.1 \%$ \\
\hline Teacher training & $31.8 \%$ \\
\hline Student issues & $17.9 \%$ \\
\hline Resources utilized & $15.7 \%$ \\
\hline
\end{tabular}

Discussion

As we found in the literature, there is a concern among employers with hiring employees who have an online accounting education. In support of our research questions, we found that $41.6 \%$ of the respondents did indicate that an accounting degree from an online university would impact their decision to hire an applicant. As expected, age had a significant impact on an employer's intention to hire an applicant. However, gender, education level, employment position, and industry did not have a significant impact on the employer's perception toward online accounting degrees.

The integrity of online courses was the first concern ranked by participants. Of the 229 responses, $68.2 \%$ indicated that this was their major concern. However, $31.77 \%$ of the survey respondents indicated that QM would change their perception of online learning in the context of online accounting education. QM not only recommends and builds in methods of protection of integrity in online courses, but it also addresses teacher training which is a concern of $31.8 \%$ of the respondents. 
In response to these concerns, an expert in online education and QM was asked to identify how current pedagogy is addressing employers' concerns. She agreed that it is easy to imagine the sense of security or freedom that an online class might provide for a student who wants to cheat. Without a doubt, online students have used resources they should not have used and even had other people take their classes for them in the past. However, technology exists to solve problems, including the problems it creates itself, so it seems naive to imagine that such a blatant problem would go unaddressed for long. The existence of a problem in the past is no indicator for that problem in the present or future; rather, it is an indicator that the appropriate tools should be found and used to prevent such a problem.

Several companies have addressed issues of cheating in online classes. With regards to tests, three leading companies are Respondus, Proctor $U$, and Examity. Each of these prevent the use of other tabs, windows, programs, and various features (such as print, screen share, etc.) on the computer on which the test is being taken, and they each use video software to proctor the student while the test is in session. That proctoring can be provided either by a recording or by a live proctor. Before beginning the test, the student must present photo identification to prove that he or she is, in fact, the same student who is on the roster and should be taking the test. Students are also asked to show their surroundings before beginning, and the instructor may be as specific as he or she wants to be - asking the student to show the floor, ceiling, and under the desk if deemed necessary. These proctoring options maintain the convenience and flexibility that online students need while preserving the integrity of the test and course. By using such solutions, we do, in fact, know that the enrolled student is being proctored to prevent cheating.

Plagiarism prevention software is also available and typically built into the university's LMS (Learning Management System). Programs such as SafeAssign or TurnltIn provide an originality report in which content that is similar to another source is flagged and the alternative content is provided to the instructor for comparison. These tools search databases of essays and other written works, as well as the internet to provide the instructor as much information as possible. The use of such tools is evidence that the integrity of online courses is, and has been, a priority for university instructors and administration. As online education grows, such tools will be used to ensure that a quality education is delivered to students and that the same concerns are addressed that would be addressed in a face-to-face course (Smith, 2018).

As discussed in the literature review, there is research to indicate that effective online pedagogy can increase GPAs and student success. In addition, other research has found that the very attributes identified by QM as effective learning lead to higher pass rates for the CPA exam. With the concern for hiring students with an accounting degree earned online, utilizing QM in the online classroom and communicating the impact this has on the students may help alleviate some of the potential employers' concerns.

\section{Conclusion}

This study uses information found in the literature, refined through interviews and developed into a survey instrument to study the perceptions of CPAs of online accounting degrees. This study is limited in that is was restricted to the state of Oklahoma where current CPA licensure permits online education for the fulfillment of semester hour and accounting course requirements (Eligibility Checklist, n.d.).

Our results indicate that university professors should emphasize to our students, to prospective employers and advisory boards the importance accreditation standards and QM and other tools for online learning have on our course development and delivery. In particular, with the seasoned professionals who may not be aware of the current technologies and how they impact our teaching methods, we should

RICHARDS, STEVENS, SILVER \& METTS / DOI: 10.5929/2019.1.14.5 
educate our students so that they can explain this in an interview situation. By emphasizing the attention university professors are giving to upholding high standards of integrity and training, the negative perceptions of online accounting education may be overcome with knowledge.

\section{References}

150 Hour Requirement for Obtaining a CPA License. Retrieved from http://www.aicpa.org/BecomeACPA/Licensure/Requirements/Pages/defulat.aspx

Adler, J. (2001). Long-distance Learning. Crain's Chicago Business, 24(10).

Bento, R., \& White, L. (2010). Quality measures that matter. Issues in Information Science and Information Technology, 7, 61-72.

Best Business Schools. The Association to Advance Collegiate Schools of Business (AACSB). Retrieved from http://bestbizschools.aacsb.edu/undergraduate/programs

Bunker, R., \& Harris, D. (2014). Online accounting degrees: An empirical investigation of CPA exam success rates. Journal of Business and Accounting, 7(1), 86-93.

Burke, J., \& Slavin, N. (2000). Just-in-time accounting education. CPA Journal, 70(4), 46-51.

Eligibility Checklist. $\quad$ (n.d.) $\quad$ Retrieved from https://www.ok.gov/oab web/documents/Eligibility\%20Checklist\%20and\%20Self\%20E valuation.pdf

Friedman, J. (2016). Study: Enrollment in online learning up, except at for-profits. US News and World Reports. Retrieved from https://www.usnews.com/education/online- education/articles/201602-09/study-enrollment-in-online-learning-up-except-at-for-profits

Grossman, A., \& Johnson, L. (2015). Employer perceptions of online accounting degrees. Issues in Accounting Education, 31(1), 91-109.

Lindquist, Tim M. (2012, April). Online accounting degrees: Research on the quality of for-profit and notfor-profit programs. The CPA Journal, 66-71.

National Association of State Boards of Accountancy (NASBA). State Board Report. Retrieved from https://nasba.org/blog/2016/07/20/education-research-reports/

National Association of State Boards of Accountancy (NASBA). CPE Requirements. Retrieved from https://www.nasbaregistry.org/cpe-requirements

Salimi, A. (2007). The promise and challenges for distance education in accounting. Strategic Finance, January, 88(7), 19-20;53.

Scofield, B., \& Walsh, R. (2009). Student advice for online MBA accounting courses. Kentucky Journal of Excellence in College Teaching and Learning, 7, 28-35.

Seibold, K. N. (2007). Employers' perceptions of online education. (Doctoral dissertation, Oklahoma State University, Oklahoma, USA). Retrieved from http://digital.library.okstate.edu/etd/umi-okstate2378.pdf

Thiswaytothecpa.org. (2017). State and Territory Requirements. Retrieved from https://www.thiswaytocpa.com/exam-licensure/state-requirements/TX/

Zarret, S. (2016). Online Education: Global Trends and the Impact on CPAs. Retrieved from 


\section{https://www.cpaacademy.org/archived show/a0DC000000ndibdMAA}

About the Authors

Rhonda J. Richards (rrichards@se.edu) returned to Southeastern Oklahoma State University as Assistant Professor of Accounting in January 2017. She graduated with a Bachelor of Science in Accounting from Southeastern Oklahoma State University with a minor in Computer Information Systems. Upon graduation, she worked in industry as the Director of Operations for an employment company and ran her own accounting practice. In 2002, she earned her Master of Business Administration from Southwest Baptist University and began her teaching career at Southwest Baptist in the accounting and computer information systems departments. While teaching at Southwest Baptist, she passed the Certified Managerial Accountant (CMA) and the Certified Public Accounting (CPA) exams. In 2005, she joined the faculty at Southeastern Oklahoma State University. She earned her Ph.D. in Business Computer Information Systems with a minor in Accounting at the University of North Texas in 2012. From June 2014 to December 2016, she served as Dean of the College of Graduate and Professional Studies at Oklahoma Baptist University.

Robert Stevens (rstevens@se.edu) is the John Massey Endowed Chair and Professor of Business Administration at Southeastern Oklahoma State University in Durant, Oklahoma. He received his Ph.D. from the University of Arkansas in Marketing and Management with a minor in Economics and Finance. During his distinguished career, Dr. Stevens has taught at the University of Arkansas, the University of Southern Mississippi, Oral Roberts University, University of Louisiana Monroe and Hong Kong Shue Yan University. His repertoire of courses has included marketing management, business research, statistics, marketing research, and strategic management. He is the author or co-author of 30 books and well over 200 articles and cases. He has published his research findings in a number of business journals and numerous professional conference proceedings. He is co-editor of the Health Marketing Quarterly and Services Marketing Quarterly, and serves on the editorial boards of four other professional journals. Dr. Stevens has acted as a marketing consultant to local, regional, and national organizations and is the owner of two small businesses.

Lawrence Silver (Isilver@se.edu) is the John Massey Endowed Chair and Professor of Marketing at Southeastern Oklahoma State University in Durant, Oklahoma. He received his Doctorate in Business Administration (Marketing), MBA, and M.A. (Industrial/Organizational Psychology) from Louisiana Tech University and a B.A. degree (Liberal Arts) from Tulane University. In 2012, he won the ACBSP Region 6 teaching award. He also holds the Chartered Property/Casualty Underwriter (CPCU) and Chartered Life Underwriter (CLU) designations. Prior to joining the faculty at Southeastern, Lawrence taught at Louisiana Tech, Troy University, and Mississippi College. Prior to a career in academia, Lawrence owned and operated an independent insurance agency and served as an outside director for a community bank. Lawrence's primary research interests are sales and sales management, salesperson motivation, consumer behavior, and marketing strategy. He has published 20 articles in peer-reviewed journals including the Journal of Personal Selling \& Sales Management, Journal of Product \& Brand Management, The Journal of Applied Case Research, and the Journal for the Advancement of Marketing Education. Lawrence is also published in over 30 academic conference proceedings. He is the co-author of two books: The Concise Encyclopedia of Insurance Terms and a textbook, The Essentials of Marketing Research, 3rd Edition. Lawrence serves as a reviewer for many conferences and serves on the editorial review boards of Services Marketing Quarterly and Health Marketing Quarterly.

Stephanie Metts (smetts@se.edu) is an Instructor of Accounting and Business, the Assistant MBA Director, and the Special Assistant to the AACSB Coordinator in the John Massey School of Business (JMSB) 
at Southeastern Oklahoma State University. Metts earned her MBA from Southeastern (2008) and her BBA in Accounting from the University (2006). She is a Certified Public Accountant in the State of Oklahoma. She is currently pursuing her Doctorate in Business Administration in Advanced Accounting at Northcentral University. In addition to her SE duties, she oversees the accounting for three of her family's small businesses. 